\title{
Spatio-Temporal Variability of Shallow Groundwater Quality in a Hilly Red-Soil Agricultural Catchment in Subtropical Central China
}

\author{
Qiao Luo ${ }^{1,2,3}$, Yong Li1,2*, Yuyuan Li1,2, Xinliang Liu' ${ }^{1,2,3}$, Runlin Xiao ${ }^{1,2}$, Jinshui Wu ${ }^{1,2}$ \\ ${ }^{1}$ Key Laboratory of Agro-Ecological Processes in Subtropical Region, Institute of Subtropical Agriculture, \\ Chinese Academy of Sciences, Changsha, China \\ ${ }^{2}$ Changsha Research Station for Agricultural \& Environmental Monitoring, Changsha, China \\ ${ }^{3}$ The University of Chinese Academy of Sciences, Beijing, China \\ Email: ${ }^{*}$ yli@isa.ac.cn
}

Received 22 December 2014; accepted 5 January 2015; published 14 January 2015

Copyright (C) 2015 by authors and Scientific Research Publishing Inc.

This work is licensed under the Creative Commons Attribution International License (CC BY).

http://creativecommons.org/licenses/by/4.0/

(c) (i) Open Access

\section{Abstract}

Groundwater quality varies not only in space but also in time. In order to analyze the spatiotemporal variety of ground water quality, the concentration of ammonium nitrogen $\left(\mathrm{NH}_{4} \mathrm{~N}\right)$, nitrate nitrogen $\left(\mathrm{NO}_{3} \mathrm{~N}\right)$, total nitrogen (TN) and total phosphorus (TP) in very shallow groundwater were investigated in a red-soil catchment in subtropical central China, based on a three-dimensional kriging method. The spatio-temporal analysis demonstrated that $\mathrm{NH}_{4} \mathrm{~N}, \mathrm{NO}_{3} \mathrm{~N}$ and TP presented strong spatio-temporal autocorrelation (with a nugget-to-sill ratio of $<25 \%$ ) and that TN presented a moderate spatio-temporal autocorrelation (with a nugget-to-sill ratio between $25 \%$ and $75 \%$ ). According to the Chinese Groundwater Quality Standards, the ratio of areas contaminated by $\mathrm{NH}_{4} \mathrm{~N}, \mathrm{NO}_{3} \mathrm{~N}$, TN and TP to the whole catchment was $20.05 \%, 1.46 \%, 5.07 \%, 5.98 \%$, respectively. The 3D delineation of continuously dynamic variation of contaminated area indicated that the catchment's very shallow groundwater had a moderate contamination by $\mathrm{NH}_{4} \mathrm{~N}$, slight by $\mathrm{TN}$ and $\mathrm{TP}$, and almost non by $\mathrm{NO}_{3} \mathrm{~N}$. Although the contaminated area was very small, only occurring in small dispersed patches, a close attention should be paid to the shallow groundwater quality because local farmers obtain their domestic drinking water directly from this shallow groundwater without any treatment prior to consuming and the potential health hazard is considerable. The findings from this study highlight the importance of surveillance of the contaminated area over time for decision making to protect public health and maintain sustainable development of

\footnotetext{
${ }^{*}$ Corresponding author.
} 


\section{the catchment.}

\section{Keywords}

\section{Drinking Water, Nitrogen, Phosphorus, 3D Spatio-Temporal Geostatistics}

\section{Introduction}

In rural areas of China, the shallow groundwater is the source of drinking water for local farmers. The quality of the groundwater may be affected by the use of agrochemicals [1], especially the nitrogen $(\mathrm{N})$ and phosphorus $(\mathrm{P})$ fertilizers. High $\mathrm{N}$ and $\mathrm{P}$ concentrations in groundwater could pose risks to environmental quality and have potential hazards to human health including methemoglobinemia, gastric cancer, and non-Hodgkin's lymphoma [2]. The threshold of the nitrate- $\mathrm{N}\left(\mathrm{NO}_{3} \mathrm{~N}\right)$ concentration in drinking water for safe drinking was recommended as $11 \mathrm{mg} / \mathrm{L}$ by the World Health Organization and as $10 \mathrm{mg} / \mathrm{L}$ by the US Environmental Protection Agency. In the UK, the groundwater P concentration is frequently monitored against the EU drinking water standard of $2.2 \mathrm{mg} / \mathrm{L}$ [3]. According to the Chinese Groundwater Quality Standards, thresholds of $1.0 \mathrm{mg} / \mathrm{L}$ for $\mathrm{NH}_{4} \mathrm{~N}, 10 \mathrm{mg} / \mathrm{L}$ for $\mathrm{NO}_{3} \mathrm{~N}$ and $0.2 \mathrm{mg} / \mathrm{L}$ for TP in potable water were set, respectively. Assessing the groundwater quality and identifying contaminated areas play a vital role in protecting public health. However, water quality varies over both space and time [4]. Spatially, numerous studies have documented the distribution of $\mathrm{NO}_{3}-\mathrm{N}$ in groundwater and relationship between $\mathrm{NO}_{3}-\mathrm{N}$ in groundwater and agricultural activities [5] [6], land use [7], hydraulic conditions [8], topographic characteristics [9]. Temporally, historical records showed that $\mathrm{NO}_{3}-\mathrm{N}$ increased from about $2 \mathrm{mg} / \mathrm{L}$ in the early 1940s to about $15 \mathrm{mg} / \mathrm{L}$ in 2002 in the US [10]. According to [11], the concentrations of $\mathrm{N}$ and $\mathrm{P}$ during the rainy season were higher than in other months in the Taihu Lake region of China. $\mathrm{NO}_{3}-\mathrm{N}$ has already been reported as high as $67 \mathrm{mg} / \mathrm{L}$ in northern china [12]. Relatively high concentrations of $\mathrm{P}$ have been reported for some groundwater bodies [3] [13]. There were also studies in both spatial and temporal variations of nutrients $\left(\mathrm{NO}_{3}^{-}, \mathrm{PO}_{4}^{3-}, \mathrm{NH}_{4}^{+}\right)$in groundwater quality [4]. However, these studies separated space from time, only focusing on geostatistical analysis on spatial characteristics or conventional analysis on temporal trends solely. $\mathbf{N}$ and $\mathrm{P}$ in the groundwater often follow complex hydrological pathways [14] [15] and have impacts over the catchment scale. Moreover, the concentration of $\mathrm{N}$ and $\mathrm{P}$ are also affected by the weather condition such as precipitation and agricultural activities such as fertilizing which occurred chronologically, and the current status of $\mathrm{N}$ and $\mathrm{P}$ have impacts on their succedent status. Therefore, it is essential to integrate spatial characteristics and temporal trends of groundwater quality with respect to both $\mathrm{N}$ and $\mathrm{P}$ at catchment scale. In the last decades, several efforts have been made for the spatio-temporal modeling [16]. Reference [17] derived a spectral approach that allowed one to obtain many classes of non-separable, spatio-temporal stationary covariance functions, and [18] worked a natural generalization by using completely monotone functions and functions whose first derivative was completely monotone [16]. References [19] and [20] introduced a product-sum model. A Bayesian maximum entropy (BME) method was used for the space/time estimation of Petrachloroethylene in New Jersey [21]. Reference [22] applied three fully spatio-temporal methods to interpolate PM10 measurements in Europe: a metric model (3D kriging), a separable covariance function and a product-sum covariance function, and found that the 3D kriging approach performed best based on the statistical analysis. The 3D kriging assumes time to be a third orthogonal dimension with identical correlation structure for spatial, temporal and spatio-temporal distances. Thus, the space-time variable of interest is treated as a sum of independent stationary spatial, temporal, and spatio-temporal components, which leads to a sum-metric space-time semivariogram model.

The Jinjing River, which is located in southern subtropical China, is a headwater tributary of the middle reach of the Yangtze River. The Jinjing catchment, which is a hilly red-soil agricultural catchment, is at risk of pollution due to excessive nutrient inputs from point and nonpoint sources. Therefore, it is important to investigate the variability of groundwater quality to identify when, where and how severe the groundwater is contaminated in this catchment. In this study, the 3D spatio-temporal analysis was performed to evaluate the spatio-temporal variability of very shallow groundwater quality throughout the Jinjing catchment. 


\section{Materials and Methods}

\subsection{Study Area}

This study was carried out in the Jinjing catchment in Changsha County, Hunan province (Figure 1) which covers an area of $135 \mathrm{~km}^{2}$. The climate is characterized as subtropical moist monsoon. The annual precipitation was $1330 \mathrm{~mm}$ (1955-2010), 66.5\% of which fell during the warm and rainy season from May to August. The annual mean air temperature was $17.5^{\circ} \mathrm{C}(1955-2010)$. The topography of the area is hilly with elevation ranging from 52 to $494 \mathrm{~m}$ above sea level. The two dominant soil types are Ultisols (USDA soil classification), or Kastanozems (FAO/UNESCO soil classification) or red soils (Chinese soil classification) (57\%), which was mainly derived from slate shale and granite, and Inceptisols (USDA soil classification) or Anthrosols (FAO/UNESCO soil classification) or paddy soils (Chinese soil classification) (42\%), which was derived from alluvial deposit of rivers. The average soil $\mathrm{pH}$ is 4.5 [23]. The average groundwater depth below the soil surface is $0.5 \mathrm{~m}$ to $5.0 \mathrm{~m}$ across the entire catchment. Woodland (65\%) and paddy fields (27\%) are the primary land-use types in the region. The study area has been dominated by a double rice cropping management.

\subsection{Groundwater Sampling}

A total of 199 Polyvinyl chloride (PVC) pipes with inside diameters of $5 \mathrm{~cm}$ were installed throughout the catchment in April 2010 for groundwater sampling. These PVC pipes reached various depths $(100$ to $130 \mathrm{~cm})$ depending on soil character. The bottom of the pipes was designed for clay soil to allow the penetration of groundwater into the pipe. A hand vacuum pump was used to sample the accumulated shallow groundwater in the pipes. Each pipe was sampled monthly in 2011. The locations of the pipes were determined by a hand-held Global Positioning System (GPS) receiver and are shown in Figure 1. All the water samples were collected in pre-cleaned polythene bottles $(500 \mathrm{ml})$, stored in the insultation box and transported to the laboratory in two hours. Samples were then stored in a freezer at $-20^{\circ} \mathrm{C}$ and subsequently the analyses for $\mathrm{NH}_{4} \mathrm{~N}, \mathrm{NO}_{3} \mathrm{~N}$, TN and TP were carried out within two weeks using a FOSS FIAstar 5000 Flow Injection Analyzer. Once the samples were taken out of the freezer, their chemical analyses were finished in 12 hours.

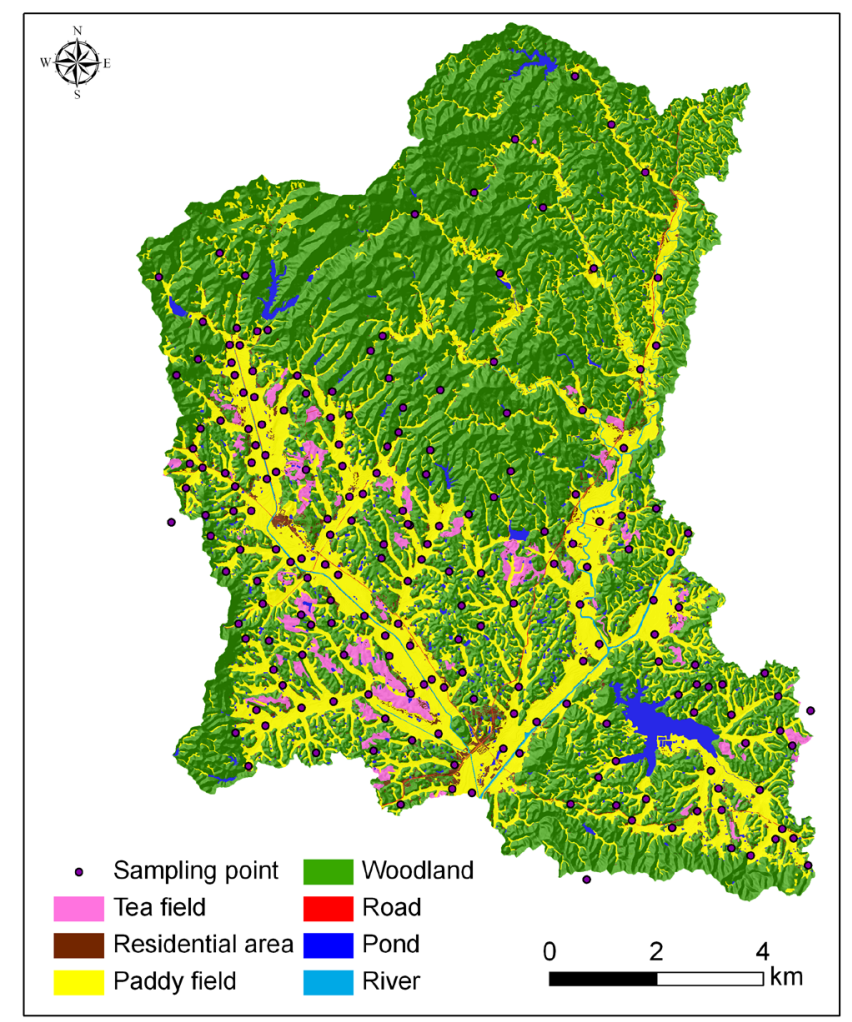

Figure 1. Sampling points and land use type in Jinjing catchment. 


\subsection{Data Preprocessing}

Summary statistics of the data are shown in Table 1 . The mean concentration of $\mathrm{NH}_{4} \mathrm{~N}, \mathrm{NO}_{3} \mathrm{~N}$, TN and TP was 1.192, 1.112, 2.836 and $0.071 \mathrm{mg} / \mathrm{L}$, respectively. The skewnesses revealed asymmetry and the kurtosises showed a stretching of the distribution of the data. The logit-transformation normalized the data and reduced this asymmetry.

\subsection{Three Dimensional Kriging}

For analyzing the spatio-temporal variability of ground water quality, we considered time as the third orthogonal dimension leading to a natural spatio-temporal 3-dimensional kriging (3D kriging) extension of spatial 2-dimensional kriging (2D kriging). Considering that the unit of distance in time was not the same as the unit of distance in space, one month was assumed to correspond to a distance of 500 meters [22]. Such an assumption enabled the researchers to generate a single spatio-temporal semivariogram and predict any point in the spacetime cube. Under the intrinsic stationarity assumption, the spatio-temporal logit-transformed semivariograms in three dimensions were then calculated as the following:

$$
\lambda\left(h_{s t}\right)=\left[2 N\left(h_{s t}\right)\right]^{-1} \sum_{i=1}^{N\left(h_{s t}\right)}\left[Z\left(x_{i}\right)-Z\left(x_{i}+h_{s t}\right)\right]^{2}
$$

where $h_{s t}$ is the spatio-temporal lags, $N\left(h_{s t}\right)$ is the number of pairs of observations with the same distance $h_{s t}$, $Z\left(x_{i}\right)$ and $Z\left(x_{i}+h_{s t}\right)$ is the spatio-temporal observations at point $x_{i}$ and $x_{i}+h_{s t}$, respectively. To predict the value of $Z$ at any unobserved points, the 3D kriging yields the best unbiased linear predictor of $Z\left(x_{0}\right)$ as:

$$
Z^{*}\left(x_{0}\right)=\sum_{i=1}^{n} \lambda_{i} Z\left(x_{i}\right)
$$

with

$$
\sum_{i=1}^{n} \lambda_{i}=1
$$

where $Z^{*}\left(x_{0}\right)$ is the estimated value of $Z$ at the unobserved point $x_{i}$, and $\lambda_{i}$ is the $n$ weights assigned to the observation points $Z\left(x_{i}\right)$ located in the neighborhood with the sum of $\lambda_{i}$ equals to 1 .

Five parameters, including three angles (ang1, ang2, and ang3) and two ratios ( $\mathrm{k} 1$ and $\mathrm{k} 2$ ), should be given in 3D kriging when geometric anisotropy was considered. ang1 refers to the principal direction of continuity (measured in degrees, clockwise from $Y$, in direction of $X$ ), ang2 is the dip angle for the principal direction of continuity (measured in positive degrees up from horizontal), and ang3 is the third rotation angle which rotates

Table 1. Statistical summary of original and logit transformed $\mathrm{NH}_{4} \mathrm{~N}, \mathrm{NO}_{3} \mathrm{~N}, \mathrm{TN}$ and $\mathrm{TP}$.

\begin{tabular}{ccccccccc}
\hline & \multicolumn{4}{c}{ Original } & \multicolumn{5}{c}{ Logit Transformed } \\
\cline { 2 - 8 } & $\mathrm{NH}_{4} \mathrm{~N}$ & $\mathrm{NO}_{3} \mathrm{~N}$ & $\mathrm{TN}$ & $\mathrm{TP}$ & Logit-NH \\
& & & $\mathrm{N}$ & Logit-NO ${ }_{3} \mathrm{~N}$ & Logit-TN & Logit-TP \\
\hline Number of Points & 1850 & 1850 & 1849 & 1849 & 1850 & 1850 & 1849 & 1849 \\
Minimum & 0.000 & 0.000 & 0.000 & 0.000 & -11.170 & -10.650 & -11.510 & -9.306 \\
$1^{\text {st }}$ Qu. & 0.026 & 0.174 & 0.710 & 0.016 & -7.874 & -5.476 & -4.939 & -6.471 \\
Median & 0.068 & 0.483 & 1.385 & 0.029 & -6.935 & -4.453 & -4.265 & -5.902 \\
Mean & 1.192 & 1.112 & 2.836 & 0.071 & -6.440 & -4.789 & -4.190 & -5.841 \\
$3^{\text {rd }}$ Qu. & 0.619 & 1.109 & 2.803 & 0.052 & -4.732 & -3.607 & -3.546 & -5.331 \\
Maximum & 70.877 & 40.170 & 98.200 & 9.513 & 6.357 & 3.089 & 4.002 & 1.856 \\
Kurtosis & 121.667 & 78.276 & 93.815 & 693.037 & 3.328 & 4.855 & 6.284 & 6.064 \\
Skewness & 9.399 & 7.337 & 7.727 & 22.990 & 0.299 & -1.048 & 0.593 & 0.259 \\
\hline
\end{tabular}


the two minor directions around the principal direction defined by ang1 and ang2. Anisotropy k1 and k2 are the ratios between the major range and each of the two minor ranges. By introducing a coordinate transformation matrix, anisotropy can be reduced to isotropy [24].

These approaches were implemented in R [25] and heavily rely on the R package gstat.

\subsection{Evaluation Standards of Groundwater Quality}

There were three evaluation standards in terms of groundwater or drinking water quality in China, which were environmental quality standards for surface water, quality standards for ground water and drinking water. Quality standards for ground water and drinking water were not adopted because there were no criteria for TN and TP in both of them. According to environmental quality standards for surface water for criterion III which is legislated for drinking water, the thresholds of the safe level for $\mathrm{NH}_{4}-\mathrm{N}, \mathrm{NO}_{3}-\mathrm{N}, \mathrm{TN}$ and $\mathrm{TP}$ are 1.0, 10, 1.0 and $0.2 \mathrm{mg} / \mathrm{L}$, respectively. However, it is surprising that the threshold of the safe level for TN $(1.0 \mathrm{mg} / \mathrm{L})$ was much lower than that of $\mathrm{NO}_{3}-\mathrm{N}(10 \mathrm{mg} / \mathrm{L})$. The threshold of the safe level for $\mathrm{NO}_{3}-\mathrm{N}$ in drinking water is recommended as $10 \mathrm{mg} / \mathrm{L}$ by the USA, which is consistent with that recommended by GB 3838-2002. Therefore, the safe level for TN was set to $10 \mathrm{mg} / \mathrm{L}$ in this study. Therefore, the thresholds of the safe level for $\mathrm{NH}_{4}-\mathrm{N}, \mathrm{NO}_{3}-\mathrm{N}$, $\mathrm{TN}$ and TP are 1.0, 10, 10 and $0.2 \mathrm{mg} / \mathrm{L}$, respectively.

\section{Results and Discussion}

\subsection{Spatio-Temporal Statistics}

The logit-transformed spatio-temporal semivariograms of the four groundwater quality variables are shown in Figure 2. The range of $\mathrm{NH}_{4} \mathrm{~N}, \mathrm{NO}_{3} \mathrm{~N}, \mathrm{TN}$ and $\mathrm{TP}$ was $828 \mathrm{~m}, 836 \mathrm{~m}, 1079 \mathrm{~m}$ and $811 \mathrm{~m}$, respectively (Figure 2). The computed model parameters are presented in Table 2. The fitted semivariogram models for the four variables are all Stein's parameterized Matern (ste). The spatio-temporal semivariogram may be affected by intrinsic and/or extrinsic factors and can be classified into three categories according to a nugget-to-sill ratio (\%), with a ratio of $<25 \%$ indicating a strong spatio-temporal dependence, a ratio of $25 \%-75 \%$ indicating a moderate spatio-temporal dependence and a ratio of $>75 \%$ indicating a weak spatio-temporal dependence [26]. In this study, it is noteworthy that all the ratios of nugget-to-sill for $\mathrm{NH}_{4} \mathrm{~N}, \mathrm{NO}_{3} \mathrm{~N}$, and TP equal to zero as well, which showed a strong spatio-temporal dependence which might be completely attributed to intrinsic factors (e.g., physical, chemical, and biological characteristics of the landscape, and hydraulic and geographic conditions). In addition, the ratio of nugget-to-sill for $\mathrm{TN}$ is $35 \%$, showing a moderate spatio-temporal dependence, which might be both determined by extrinsic factors (e.g., fertilizer application and animal wastes) and intrinsic factors. Anisotropy parameters are also shown in Table 2. It is noteworthy that the distribution of TP was isotropic.

Leave-One-Out cross-validation analysis was performed to evaluate the accuracy of the interpolation of the 3D kriging. The mean prediction error (ME) and the root mean squared error (RMSE) were then used to evaluate the performance of the interpolation, as well as the correlation coefficient (r). Ideally, ME should be close to zero, RMSE should be as small as possible, and $r$ should be close to 1 . The result of leave-one-out cross validation analysis was shown in Table 2. It was found that the ME was close to 0 (between -0.019 and -0.00005 ), the RMSE ranged from 0.867 to 1.843 and r ranged from 0.38 to 0.64 , indicating an accuracy of predictions.

\subsection{Spatio-Temporal Distributions}

$\mathbf{N H}_{4} \mathbf{N}$. As shown in Figure 3, the concentration of $\mathrm{NH}_{4} \mathrm{~N}$ was high (up to $70 \mathrm{mg} / \mathrm{L}$ ) which occurred in April, exceeding the safety threshold of $1.0 \mathrm{mg} / \mathrm{L}$ by 70 times. $20.05 \%$ of the data collected from January to December exceeded the safety threshold. The concentration of $\mathrm{NH}_{4} \mathrm{~N}$ is less than $0.15 \mathrm{mg} / \mathrm{L}$ for most area of the catchment. It is noteworthy that there is always a high ammonium concentration center in the northeast of the catchment, especially in May, June and July, which is shown as red in Figure 3.

$\mathbf{N O}_{3} \mathbf{N}$. As shown in Figure 4, the highest concentration of $\mathrm{NO}_{3} \mathrm{~N}$ reached $40 \mathrm{mg} / \mathrm{L}$, exceeding the safety threshold of $10 \mathrm{mg} / \mathrm{L}$ by 4 times, although only $1.46 \%$ of the observations exceeded the safety threshold. The maximum nitrate concentration just occurred in January as a point, standing till April. Most areas of the catchment remain uncontaminated by $\mathrm{NO}_{3} \mathrm{~N}$ with concentrations between 0.2 and $0.5 \mathrm{mg} / \mathrm{L}$.

TN. As shown in Figure 5, the highest concentration of TN reached $55 \mathrm{mg} / \mathrm{L}$, exceeding the safety threshold 

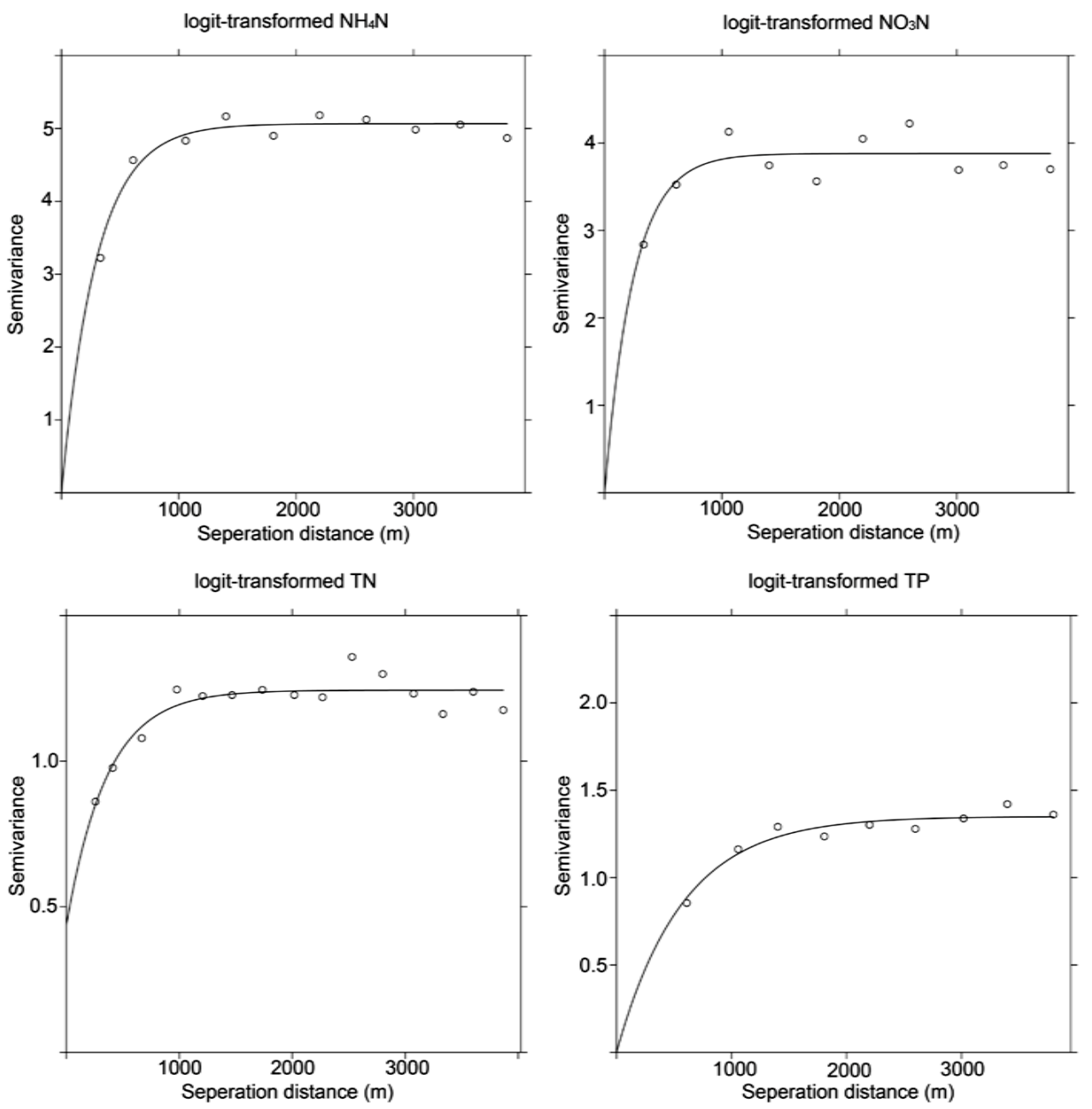

Figure 2. Three dimensional semivariance of the logit-transformed ammonium nitrogen $\left(\mathrm{NH}_{4} \mathrm{~N}\right)$, nitrate nitrogen $\left(\mathrm{NO}_{3} \mathrm{~N}\right)$, total nitrogen $(\mathrm{TN})$ and total phosphorus (TP) concentrations. Distance corresponds to meters, where a temporal difference of 1 month equals $500 \mathrm{~m}$. The semivariance in $X-Y$ planes, $Z$ plane, and $X-Y-Z$ planes represented spatial, temporal, and spatio-temporal semivariance respectively.

Table 2. Model parameters for $3 \mathrm{D}$ semivariograms of logit-transformed $\mathrm{NH}_{4} \mathrm{~N}, \mathrm{NO}_{3} \mathrm{~N}, \mathrm{TN}$ and $\mathrm{TP}$ concentrations.

\begin{tabular}{|c|c|c|c|c|c|c|c|c|c|c|c|c|}
\hline \multirow{2}{*}{ Variable } & \multicolumn{4}{|c|}{ Semivariogram model parameter } & \multicolumn{5}{|c|}{ Anisotropy parameter } & \multicolumn{3}{|c|}{ Leave-one-out cross validation } \\
\hline & Range (m) & Model & Nugget & Psill & Ang1 (degree) & Ang2 (degree) & Ang3 (degree) & Ratio1 & Ratio2 & ME & RMSE & $\mathrm{r}$ \\
\hline $\mathrm{NH}_{4} \mathrm{~N}$ & 828 & ste & 0 & 5.065 & 90 & 90 & 0 & 0.51 & 0.49 & -0.015 & 1.843 & 0.62 \\
\hline $\mathrm{NO}_{3} \mathrm{~N}$ & 836 & ste & 0 & 3.88 & 95 & 100 & 102 & 0.5 & 0.415 & -0.00005 & 1.552 & 0.62 \\
\hline $\mathrm{TN}$ & 1079 & ste & 0.437 & 0.806 & 84 & 82 & 0 & 0.469 & 0.509 & -0.019 & 0.867 & 0.64 \\
\hline ТP & 811 & ste & 0 & 1.35 & - & - & - & - & - & 0.009 & 1.071 & 0.38 \\
\hline
\end{tabular}

of $10 \mathrm{mg} / \mathrm{L} 5.5$ by times, and 5.07\% of the observations exceeded the safety threshold. Compared with spatiotemporal variability of $\mathrm{NH}_{4} \mathrm{~N}$ in Figure 3, the high TN concentration center appeared in May, June and July, which was consistent with that of $\mathrm{NH}_{4} \mathrm{~N}$ in the northeast of the catchment. While compared with spatio-temporal variability of $\mathrm{NO}_{3} \mathrm{~N}$ in Figure 4, the high TN concentration center appeared in January, February, March and April was also demonstrated in Figure 5. Except for the high TN concentration centers, most areas of the catchment remain uncontaminated by TN with concentrations between 1.0 and $2.0 \mathrm{mg} / \mathrm{L}$. 


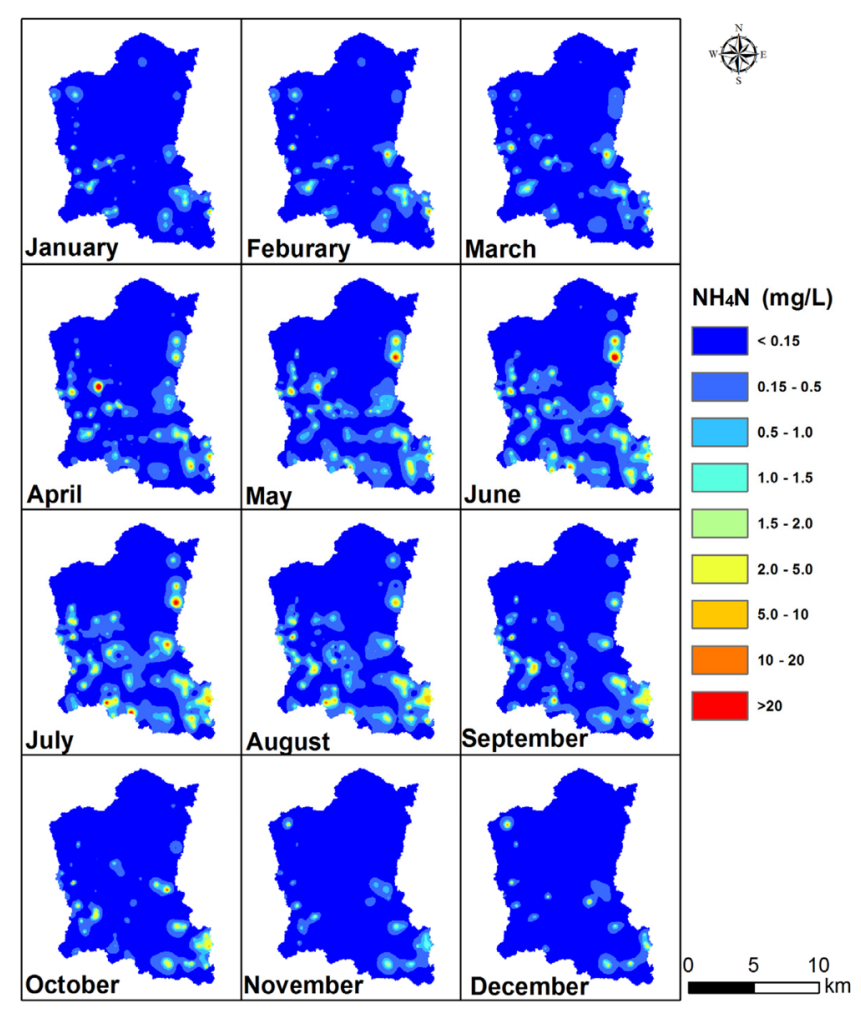

Figure 3. Estimated $\mathrm{NH}_{4} \mathrm{~N}$ over Jinjing catchment from January to December in 2011 monthly, mg/L.

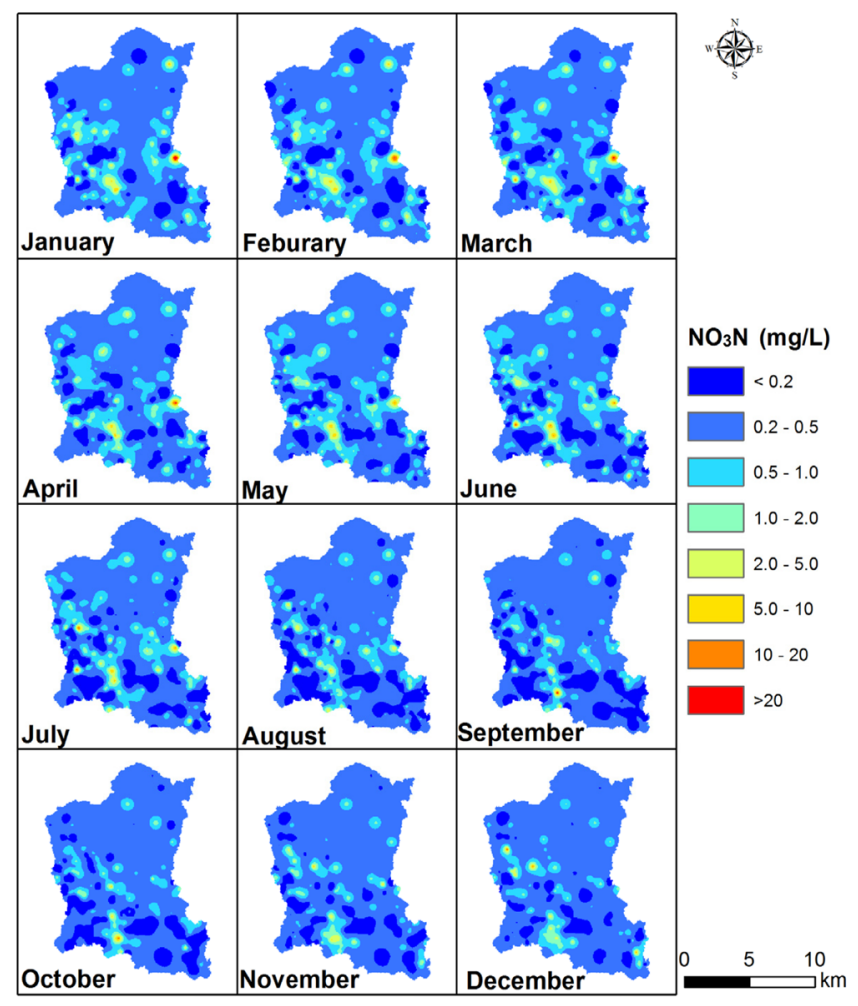

Figure 4. Estimated $\mathrm{NO}_{3} \mathrm{~N}$ over Jinjing catchment from January to December in 2011 monthly, $\mathrm{mg} / \mathrm{L}$. 


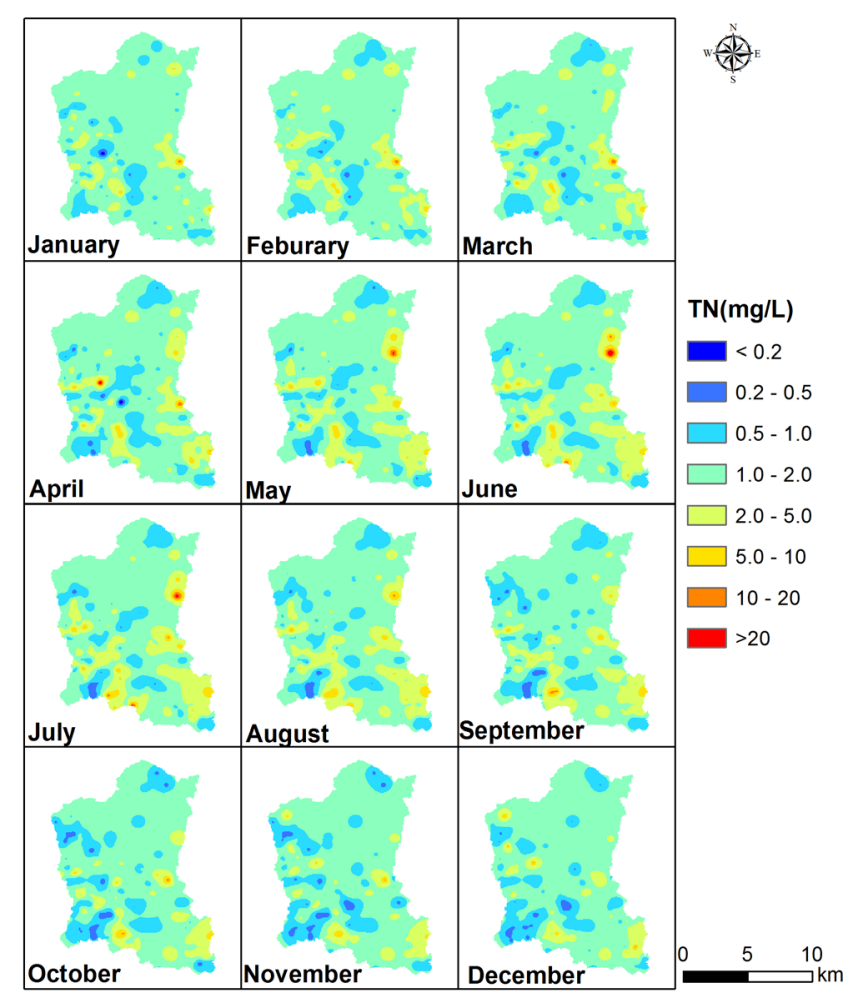

Figure 5. Estimated TN over Jinjing catchment from January to December in 2011 monthly, mg/L.

TP. As shown in Figure 6, the highest concentration of TP reached $10 \mathrm{mg} / \mathrm{L}$, exceeding the safety threshold of $0.2 \mathrm{mg} / \mathrm{L}$ by 50 times, and $5.98 \%$ of the observations exceeded the safety threshold. Most of the area in the catchment remains uncontaminated by TP with concentrations between 0.02 and $0.1 \mathrm{mg} / \mathrm{L}$. The high TP concentration centers flashed in the center of the Jinjing catchment in April and in December. In addition, there were two hot-spots in northeast and south of the area in May and June, suggesting the existence of the potential anthropogenic point sources.

Figure 7 portrays the continuously dynamic variation of contaminated area of $\mathrm{NH}_{4} \mathrm{~N}, \mathrm{NO}_{3} \mathrm{~N}, \mathrm{TN}$ and $\mathrm{TP}$. Comparing numbers and volume of spatio-temporal cube in Figures 7(a)-(d), the catchment was more seriously polluted by $\mathrm{NH}_{4}-\mathrm{N}$, moderately polluted by $\mathrm{TP}$ and $\mathrm{TN}$, and lowest polluted by $\mathrm{NO}_{3}-\mathrm{N}$. Contamination of $\mathrm{NH}_{4}-\mathrm{N}$ mainly occurred in May, June, July and August, which was during the period of rice growth and fertilizer application, indicating that rice agriculture had a negative effect on the shallow groundwater quality. The higher contamination level of $\mathrm{NH}_{4}-\mathrm{N}$ than that of $\mathrm{NO}_{3}-\mathrm{N}$ might be attributed to the low nitrification rate. For one thing, red soil (Ultisols and Oxisols in US Soil Taxonomy) is the dominant soil type in this catchment with a low pH of 4.5 [23] resulting in a low nitrification potential. For another, the short distance between top soil and shallow groundwater, which was only 100 to $130 \mathrm{~cm}$, restrict the nitrification time, resulting in small rates of nitrification. Further investigation of soil and deep groundwater $\mathrm{NH}_{4} \mathrm{~N}$ and $\mathrm{NO}_{3} \mathrm{~N}$ concentration is needed to clarify this problem.

Most of the area in the catchment was not contaminated by TP, due to the fact that phosphorus can be adsorbed by natural sediments and pure minerals in soil, resulting in small rates of phosphorus transport to groundwater [11]. Generally, transport of phosphorus to groundwater is assumed to be not important because of the high potential for mobile phosphorus to be retained in the upper soil horizons by adsorption or metal complex formation [27].

\section{Conclusions}

This study investigated the potential of 3D kriging approach for spatio-temporal variability of groundwater quality with $\mathrm{NH}_{4} \mathrm{~N}, \mathrm{NO}_{3} \mathrm{~N}$, TN and TP concentrations which were measured monthly in the Jinjing catchment for the 


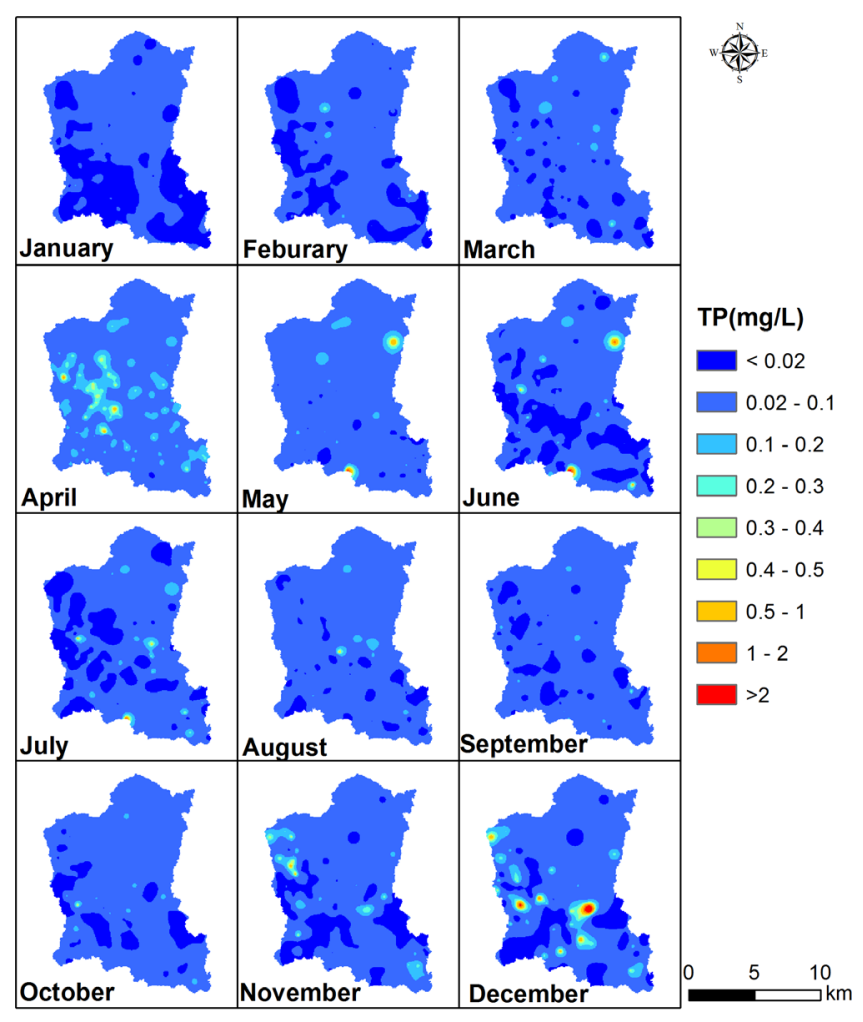

Figure 6. Estimated TP over Jinjing catchment from January to December in 2011 monthly, mg/L.

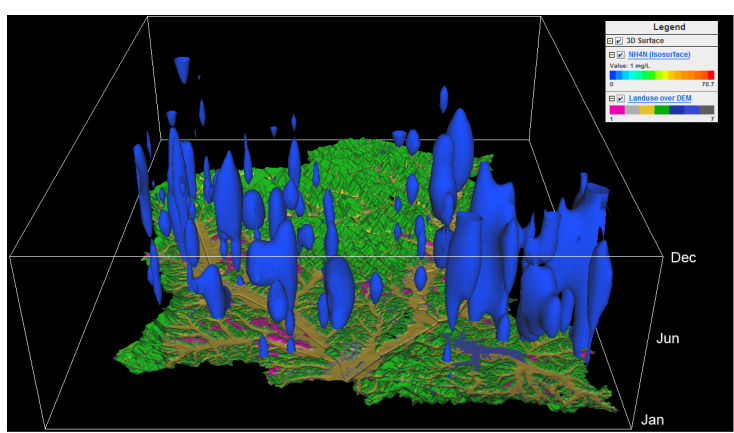

(a)

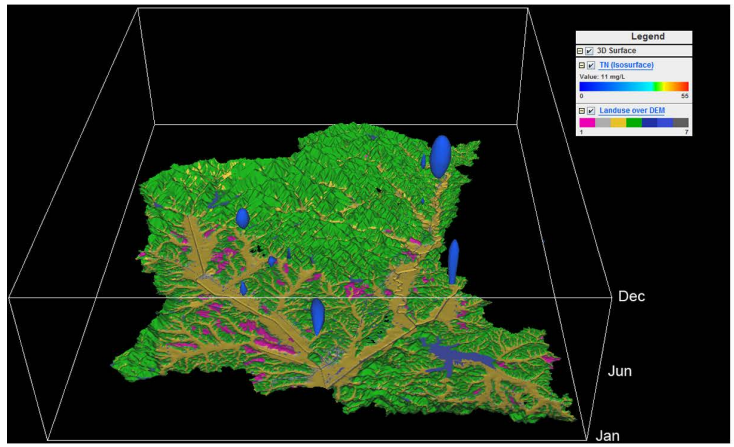

(c)

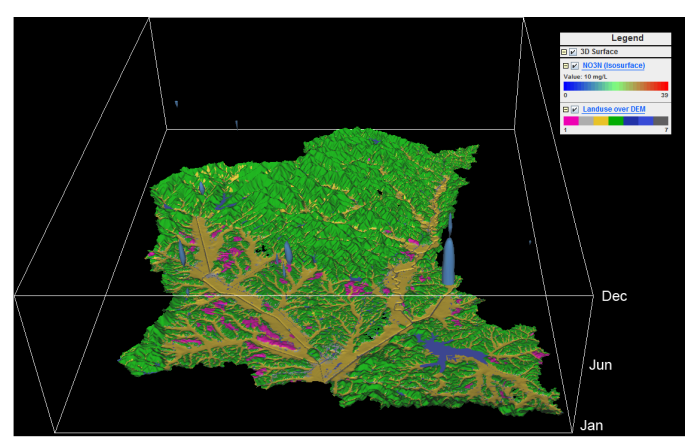

(b)

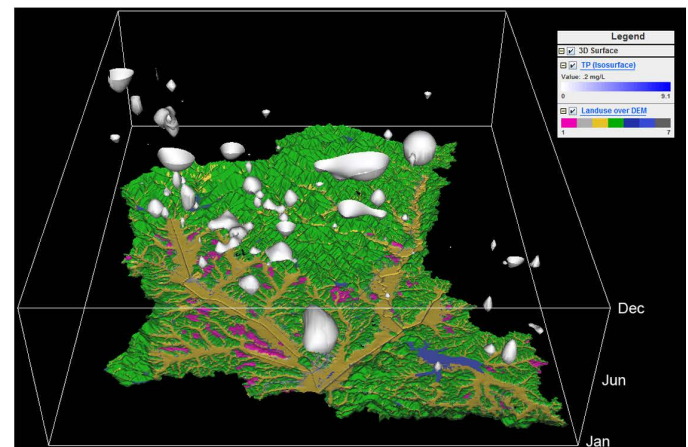

(d)

Figure 7. Three dimensional display for spatio-temporal dynamic variation of contaminated area of ammonium nitrogen (a), nitrate nitrogen (b), total nitrogen (c) and total phosphorus (d). 
year 2011. According to the spatio-temporal variability of $\mathrm{NH}_{4} \mathrm{~N}, \mathrm{NO}_{3} \mathrm{~N}, \mathrm{TN}$ and $\mathrm{TP}$, the contaminated area was small, only appeared in small dispersed patches, however, close attention should be paid to the shallow ground water quality because local farmers obtain their drinking water directly from domestic wells without any treatment and potential harmful effects on human health are considerable. Moreover, closer attention should be paid to the scientific explanation and fundamental understanding of other variables governing spatial variation and temporal processes which are related to these four variables addressed in this study.

Highlighting the contaminated area over time plays a significant role for decision makers to protect public health and maintain sustainable development of the catchment. Modeling the spatio-temporal variability can improve our ability to characterize and predict the contaminated area. In this study, 3D kriging was used to investigate the spatio-temporal variability of shallow groundwater quality based on the Leave-One-Out cross-validation analysis for the year of 2011. However, limitations should be pointed out because of the small density of sampling locations in the northeast of the catchment, which is mainly dominated by woodland. As it is hilly and there are few residents in this area, there are less observational points.

\section{Acknowledgements}

This work was financially supported by the National Basic Research Program of China (2012CB417105), the Chinese Academy of Sciences (KZCX2-YW-T07 and 100-Talents Program) and the State Administration of Foreign Experts Affairs of China (20100491005-8).

\section{References}

[1] Bouman, B.A.M., Castaneda, A.R. and Bhuiyan, S.I. (2002) Nitrate and Pesticide Contamination of Groundwater under Rice-Based Cropping Systems: Past and Current Evidence from the Philippines. Agriculture, Ecosystems \& Environment, 92, 185-199. http://dx.doi.org/10.1016/S0167-8809(01)00297-3

[2] Fan, A.M. and Steinberg, V.E. (1996) Health Implications of Nitrate and Nitrite in Drinking Water: An Update on Methemoglobinemia Occurrence and Reproductive and Developmental Toxicity. Regulatory Toxicology and Pharmacology, 23, 35-43. http://dx.doi.org/10.1006/rtph.1996.0006

[3] Holman, I.P., Howden, N.J.K., Bellamy, P., Willby, N., Whelan, M.J. and Rivas-Casado, M. (2010) An Assessment of the Risk to Surface Water Ecosystems of Groundwater P in the UK and Ireland. Science of the Total Environment, 408, 1847-1857. http://dx.doi.org/10.1016/j.scitotenv.2009.11.026

[4] Schot, P.P. and Pieber, S.M. (2012) Spatial and Temporal Variations in Shallow Wetland Groundwater Quality. Journal of Hydrology, 422, 43-52. http://dx.doi.org/10.1016/j.jhydrol.2011.12.023

[5] Mitchell, R.J., Babcock, R.S., Gelinas, S., Nanus, L. and Stasney, D.E. (2003) Nitrate Distributions and Source Identification in the Abbotsford-Sumas Aquifer, Northwestern Washington State. Journal of Environmental Quality, 32, 789-800. http://dx.doi.org/10.2134/jeq2003.7890

[6] Morari, F., Lugato, E., Polese, R., Berti, A. and Giardini, L. (2012) Nitrate Concentrations in Groundwater under Contrasting Agricultural Management Practices in the Low Plains of Italy. Agriculture, Ecosystems \& Environment, 147, 47-56. http://dx.doi.org/10.1016/j.agee.2011.03.001

[7] Eckhardt, D.A.V. and Stackelberg, P.E. (1995) Relation of Ground-Water Quality to Land Use on Long Island, New York. Ground Water, 33, 1019-1033. http://dx.doi.org/10.1111/j.1745-6584.1995.tb00047.x

[8] Liu, G.D., Wu, W.L. and Zhang, J. (2005) Regional Differentiation of Non-point Source Pollution of Agriculture-Derived Nitrate Nitrogen in Groundwater in Northern China. Agriculture, Ecosystems \& Environment, 107, 211-220. http://dx.doi.org/10.1016/j.agee.2004.11.010

[9] Kaown, D., Hyun, Y., Bae, G.-O. and Lee, K.-K. (2007) Factors Affecting the Spatial Pattern of Nitrate Contamination in Shallow Groundwater. Journal of Environmental Quality, 36, 1479-1487. http://dx.doi.org/10.2134/jeq2006.0361

[10] Puckett, L.J., Tesoriero, A.J. and Dubrovsky, N.M. (2011) Nitrogen Contamination of Surficial Aquifers-A Growing Legacy. Environmental Science \& Technology, 45, 839-844. http://dx.doi.org/10.1021/es1038358

[11] Chen, X.M., Wo, F., Chen, C. and Fang, K. (2010) Seasonal Changes in the Concentrations of Nitrogen and Phosphorus in Farmland Drainage and Groundwater of the Taihu Lake Region of China. Environmental Monitoring and Assessment, 169, 159-168. http://dx.doi.org/10.1007/s10661-009-1159-3

[12] Zhang, W.L., Tian, Z.X., Zhang, N. and Li, X.Q. (1996) Nitrate Pollution of Groundwater in Northern China. Agriculture, Ecosystems \& Environment, 59, 223-231. http://dx.doi.org/10.1016/0167-8809(96)01052-3

[13] Kilroy, G. and Coxon, C. (2005) Temporal Variability of Phosphorus Fractions in Irish Karst Springs. Environmental Geology, 47, 421-430. http://dx.doi.org/10.1007/s00254-004-1171-4 
[14] Sharpley, A.N. and Rekolainen, S. (1997) Phosphorus in Agriculture and Its Environmental Implications. In: Tunney, H., Carton, O.T., Brookes, P.C. and Johnston, A.E., Eds., Phosphorus Loss from Soil to Water. Proceedings of a Workshop, Wexford, 29-31 September 1995, 1-53.

[15] Sonneveld, M.P.W., de Vos, J.A., Kros, J., Knotters, M., Frumau, A., Bleeker, A. and de Vries, W. (2012) Assessment of N and P Status at the Landscape Scale Using Environmental Models and Measurements. Environmental Pollution, 162, 168-175. http://dx.doi.org/10.1016/j.envpol.2011.11.020

[16] Huang, H.C., Martinez, F., Mateu, J. and Montes, F. (2007) Model Comparison and Selection for Stationary SpaceTime Models. Computational Statistics \& Data Analysis, 51, 4577-4596. http://dx.doi.org/10.1016/j.csda.2006.07.038

[17] Cressie, N. and Huang, H.C. (1999) Classes of Nonseparable, Spatio-Temporal Stationary Covariance Functions. Journal of the American Statistical Association, 94, 1330-1339. http://dx.doi.org/10.1080/01621459.1999.10473885

[18] Gneiting, T. (2002) Nonseparable, Stationary Covariance Functions for Space-Time Data. Journal of the American Statistical Association, 97, 590-600. http://dx.doi.org/10.1198/016214502760047113

[19] De Cesare, L., Myers, D.E. and Posa, D. (2001) Estimating and Modeling Space-Time Correlation Structures. Statistics \& Probability Letters, 51, 9-14. http://dx.doi.org/10.1016/S0167-7152(00)00131-0

[20] De Iaco, S., Myers, D.E. and Posa, D. (2001) Space-Time Analysis Using a General Product-Sum Model. Statistics \& Probability Letters, 52, 21-28. http://dx.doi.org/10.1016/S0167-7152(00)00200-5

[21] Akita, Y., Carter, G. and Serre, M.L. (2007) Spatiotemporal Nonattainment Assessment of Surface Water Tetrachloroethylene in New Jersey. Journal of Environmental Quality, 36, 508-520. http://dx.doi.org/10.2134/jeq2005.0426

[22] Gräler, B., Gerharz, L. and Pebesma, E. (2011) Spatio-Temporal Analysis and Interpolation of PM10 Measurements in Europe, ETC/ACM Technical Paper 2011/10. http://acm.eionet.europa.eu/reports/ETCACM_TP_2011_10_spatio-temp_AQinterpolation

[23] Li, Y., Fu, X.Q., Liu, X.L., Shen, J.L., Luo, Q., Xiao, R.L., Li, Y.Y., Tong, C.L. and Wu, J.S. (2013) Spatial Variability and Distribution of $\mathrm{N}_{2} \mathrm{O}$ Emissions from a Tea Field during the Dry Season in Subtropical Central China. Geoderma, 193-194, 1-12. http://dx.doi.org/10.1016/j.geoderma.2012.10.008

[24] Deutsch, C.V. and Journel, A.G. (1998) GSLIB: Geostatistical Software Library and User’s Guide. 2nd Edition, Oxford University Press, Oxford.

[25] R Core Team (2013) R: A Language and Environment for Statistical Computing. R Foundation for Statistical Computing, Vienna. http://www.r-project.org/

[26] Cambardella, C.A., Moorman, T.B., Novak, J.M., Parkin, T.B., Karlen, D.L., Turco, R.F. and Konopka, A.E. (1994) Field-Scale Variability of Soil Properties in Central Iowa Soils. Soil Science Society of America Journal, 58, 15011511. http://dx.doi.org/10.2136/sssaj1994.03615995005800050033x

[27] Addiscott, T.M. and Thomas, D. (2000) Tillage, Mineralization and Leaching: Phosphate. Soil and Tillage Research, 53, 255-273. http://dx.doi.org/10.1016/S0167-1987(99)00110-5 
Scientific Research Publishing (SCIRP) is one of the largest Open Access journal publishers. It is currently publishing more than 200 open access, online, peer-reviewed journals covering a wide range of academic disciplines. SCIRP serves the worldwide academic communities and contributes to the progress and application of science with its publication.

Other selected journals from SCIRP are listed as below. Submit your manuscript to us via either submit@scirp.org or Online Submission Portal.
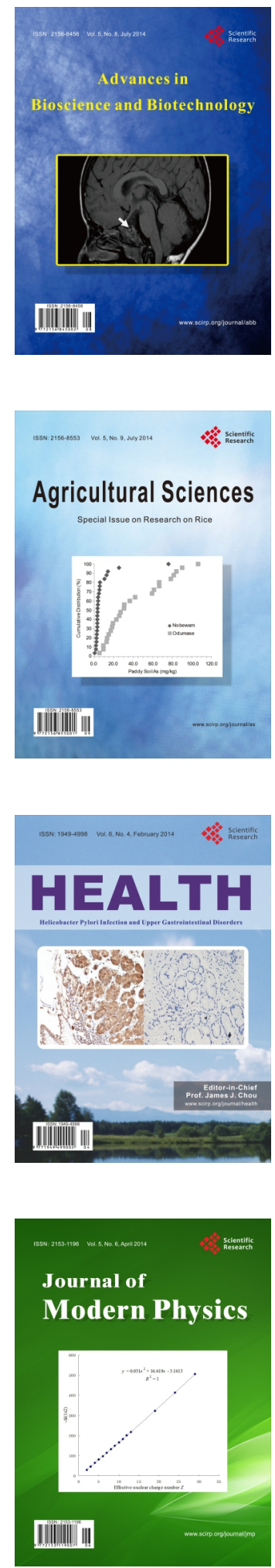
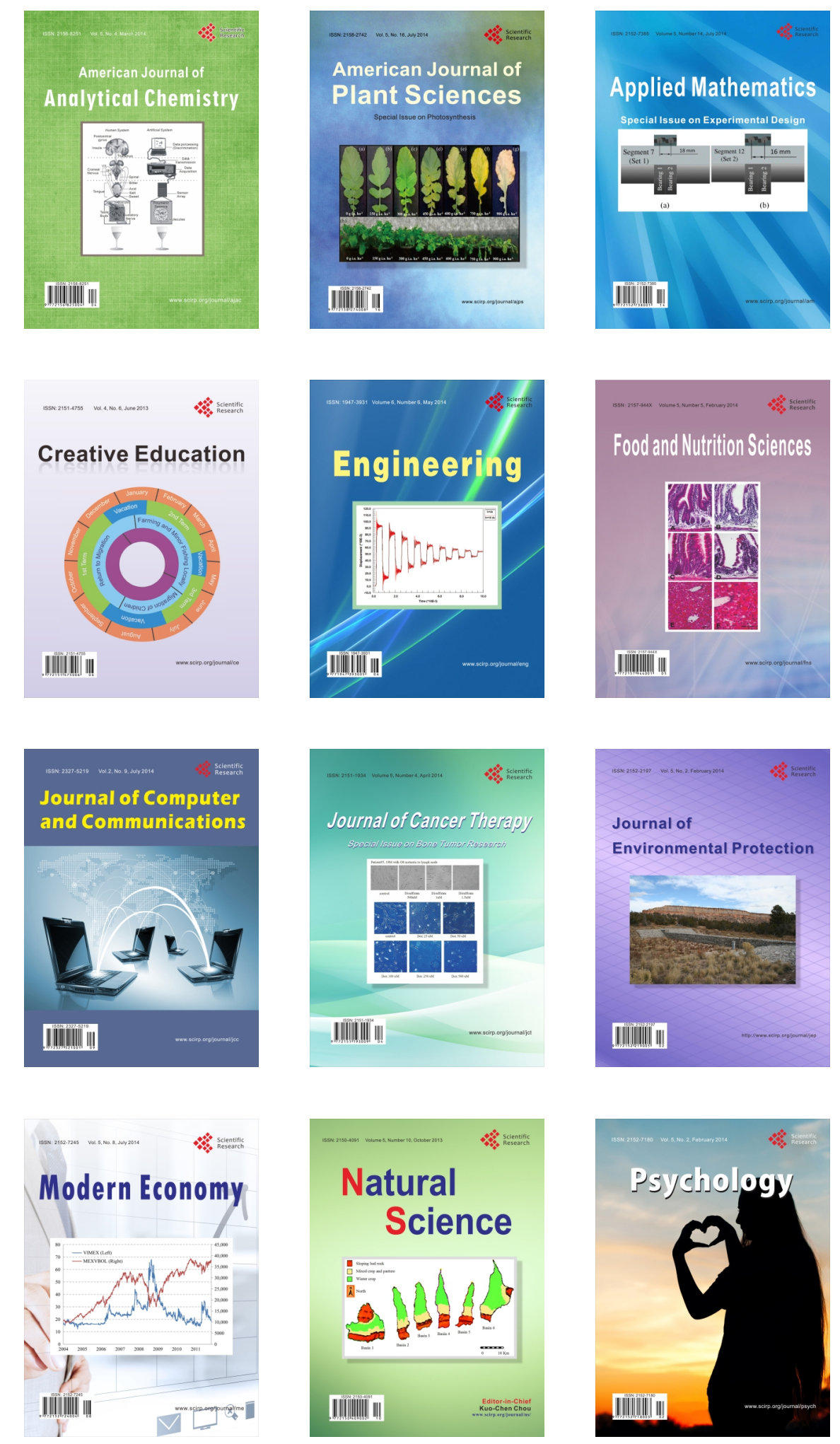